\title{
The Influence of Modified Games and Conventional Learning Models on the Physical Fitness of Junior High School Students
}

\author{
Khairuddin $^{1}$ \\ ${ }^{1}$ Universitas Negeri Padang, Indonesia \\ Correspondence: Khairuddin, Faculty of Sports Science, Universitas Negeri Padang, J1. Prof. Dr. Hamka - Air \\ Tawar, Padang, Sumatera Barat, Indonesia. E-mail: khairuddin.ai@gmail.com
}

Received: February 12, 2014 Accepted: February 20, 2014 Online Published: February 28, 2014

doi:10.5539/ass.v10n5p136 URL: http://dx.doi.org/10.5539/ass.v10n5p136

\begin{abstract}
The purpose of this research is to determine the effectiveness of two learning models in improving the physical fitness of junior-high-school students. The samples for this quasi experimental research were 40 junior high school students chosen randomly from a population of 96 . The instrument used to measure physical fitness is the Indonesian Physical Fitness Test (TKJI). Data is analyzed by using t-test. Data analysis showed that the game-modification learning model can significantly improve the student physical fitness, the conventional learning model did not improve the student physical fitness significantly, and the game-modification learning model is better in improving the physical fitness than the conventional learning. Therefore, it can be concluded that the game-modification learning model is better in improving students' physical fitness than the conventional learning model.
\end{abstract}

Keywords: learning models, modified games, conventional, physical fitness

\section{Introduction}

A good physical fitness is necessary for all students from kindergarten to colleges. A fit student can do daily activities for a longer period than a less-fit student (Adisapoetra, 1999: 1). This is in accordance with the opinion of Moeloek (1984), stating that improved the development of Indonesian people today, physical fitness must be owned by any individual according to their respective. A fit student will have the ability to do work in his/her daily living without undue fatigue and s/he can still enjoy his/her leisure time and face unexpected circumstances. This opinion is similar to Nieman (1990), saying that individuals with good physical fitness will be able to carry out daily tasks in full spirit and vigilance without fatigue and still has energy to enjoy leisure time activities and deal with emergencies.

From the above explanations it is obvious that to develop a wholesome Indonesian citizens, individuals must have good physical fitness so that daily activities can be done effectively and efficiently. Students physical fitness can be improve through the learning process of physical education in schools. This is in line with the objective of Health and Physical Education in schools besides improving cognition, psychomotor and affection domains (Samsudin, 2008). Therefore, physical education teachers must have the ability to plan a good physical education learning process in order to increase student physical fitness.

Recently a research conducted by the Center for Quality Physical Development of National Education Ministry on elementary, junior high, senior high and vocational schools students in Indonesia concluded that physical fitness of $11 \%$ of the students were in the very poor category, $45.8 \%$ in poor category, $36.5 \%$ in average category, $4.1 \%$ in good category and none in the excellent category (Widodo, 2004). Junior-high-school students in Padang City have rather similar categories to those obtained in the above research. Research conducted among male junior high school students in the city of Padang, Indonesia showed that no students is in the excellent category of physical fitness, $22.7 \%$ in the good category, $27.2 \%$ in the average category, $13.64 \%$ in the poor fitness category, and $36.36 \%$ with very poor fitness category (Arman, 2007).

The decreasing physical fitness levels of students in both national level and Padang city shows that the current learning process of physical education conducted at schools is not effective in increasing fitness of students. This means that one of the expected learning objectives is not achieved. The approach to learning physical education in the city of Padang is still traditional and conventional. In other words, teachers' uses instructions and 
repetitious practice to acquire proficiency in skill without concluding with game situations thus students are less active during the learning process.

Based on the background of research, a research was conducted to answer the following questions, i) Can physical education with game modification learning model significantly improve the students' physical fitness? ii) Can physical education with conventional learning model significantly improve the students' physical fitness? iii) Is the learning model with game modification better than the conventional learning model in improving the students' physical fitness?

\subsection{Physical Fitness}

The definition of physical fitness is the ability to do daily activities without fatigue, and still have adequate energy for leisure time and to act during emergencies (http://www.indiana.edu/ preschool). Moreover, according to Nieman (1990), a physically fitis someone who is capable to carryout daily tasks energetically and cautiously, without fatigue, and still have enough energy to enjoy leisure time activities and face emergencies. Corbin (2007) states that physical fitness is the ability of the body to do daily activities effectively and efficiently, without fatigue. Hairy (1989) states that a physically fit person is able to carry out daily tasks energetically and cautiously, without fatigue and has remaining energy that can be used to enjoy leisure time and face unexpected urgent situations. Therefore, it can be concluded that physical fitness in this research is defined as students' ability to do daily activities without fatigue and, has remaining energy, to face urgent and unexpected situations.

In addition, according to Nieman (1990) and Greenberg (2004), there are physical fitness are divided into two components, i) health-related physical fitness which includes cardiorespiratory endurance, muscle strength, muscle endurance, flexibility, and body composition; and ii) skill-related physical fitness which includes coordination, balance, speed, reaction time, power, and agility. A student with good physical fitness may show some characteristics as stated by Tohari (1985), which includes resistance to disease, has respiratory endurance, good muscle endurance, muscle strength, flexibility, and a balanced body composition. Meanwhile, the signs of low physical fitness includes drowsiness, laziness, feeling tired even with minimal physical work, too tired to enjoy leisure time, feeling nervous, cannot relax, tend to be worried, and is easily offended.

The importance of physical fitness differs from one individual to the next and is dependent on their activity level. According to Said (1979), the function of physical fitness to an individual is dependent on the needs of the persons: a) an athlete for improving his performance, a soldier for increasing and strengthening for combat work, school and college students for improving learning capability, an employee for work prestige; b) a pregnant mother in preparing for delivery, and a patient for recovering his/her health; c) children for increasing growth and development and the elderly for improving immunity from diseases.

\subsection{Learning Approach with Modified Games}

Physical education is a learning process through physical activities done by students for the cognitive, psychomotor and affective purposes which also includes physical fitness. As stated by Sukintaka (2004), when students are active during physical education classes with various games, they will unconsciously undergo changes in their cardiorespiratory endurance, muscle strength, muscle endurance, and flexibility, thus improving their physical fitness. According to Gabbard (1987), games are important to students because it can make them feel happy. Some games performed during physical education classes not only develop the students physically but also increase their basic movement skills as well as cognitive and affective domains. Moreover, as explained by Pangrazi, a game is important laboratory to learn a skill. Besides that, students involve in games also acquire benefits for physical development, gross and fine motor development, social development, emotional development, cognitive development, increase alertness, and develops sport skills (Tedjasaputera, 2005).

In addition, a theory of game as explained by Herbert Spencer in the $19^{\text {th }}$ century is energy-excess theory or "excessive energy." This theory says that the human has a number of energy harnessed in maintaining daily living. The excessive energy if not used in maintaining life can be harnessed for playing (Montolulu, 2006). From that theory, when the energy consumed daily by students from food is not used optimally in daily living, it will be excessive within their body. If this excess energy is not used up in games at school or at home, it will be accumulated and turn to fat which results in increase body weight and decrease in health and fitness.

Game modification is an alternative that can be used by physical education teacher in the learning process (Bahagia, 2000). Game modification is an attempt by a physical education teacher which reflects a developmentally appropriate practice. Therefore, it is important that this learning pays attention to some changes in student ability or condition that can trigger learning (Samsuddin, 2008). As such, the learning process used by physical education teachers must fit the development and maturation levels of their students. 
Bahagia (2000) states that learning using game modification in physical education has its advantages. Through game modification, teachers can analyze and develop the subject content by making a series of learning activities that can help students in psychomotor learning. In using the game modification approach in physical education, students will be very much involved in the activities, thus, using up more energy. This approach is dominant in improving the physical fitness component of cardio respiratory endurance.

\subsection{Learning Approach using Conventional Method}

The conventional method used in physical education classes is when teachers gave instructions and prioritize repetitive practice as the basis for acquiring skill. In this approach, apart from frequently referring to the subject content in the curriculum, teacher also controls strictly activities performed by the students. According to Monsk (cited in Haditono, 1991), conventional learning method has less influence on students' cognitive development and on experiences with their surroundings. Pangrazi (1995) explained that a conventional learning approach is accompanied with a training to focus on physical skill and synergy and to avoid affective and cognitive domains. Usually conventional physical education learning uses a series of activities consisting of the following steps: i) pre-preparation, ii) a short information on how to do the movement, iii) demonstration by the teacher, iv) a chance for students to ask question for clarification, v) student practices, vi) observation and correction by the teacher, and vii) evaluation of the practiced movements (Djamarah, 1995).

In addition, according to Pangrazi (1995), a conventional learning approach emphasizes on sports achievement. In the learning process, the teacher teaches and determines some tasks of movement to students. The aim of learning is usually mastery of some skills for sports achievement. With regard to the above explanations, the hypotheses that seeks clarification in this research were:

1) Game modification approach in learning physical education may significantly influence the physical fitness of the students.

2) Conventional approach in learning physical education may not significantly influence the physical fitness of the students.

3) Game modification approach is better in improving the students' physical fitness than the conventional approach.

\section{Methodology}

A quasi-experiment with pretest and post test group design is used in this research. The independent variables were physical education learning models with game modification and conventional approach; and the dependent variable is physical fitness score.

The target population was male students in a junior high school in the city of Padang aged between $12-14$ years of age, and 40 samples were randomly chosen for this study. The TKJI test battery for physical fitness was used $t$ collect data. Data were analyzed using t-test and the level of significant is set at $\alpha=0.05$.

\section{Results}

The data normality test is first conducted by using the Kolmogrov-Smirnov formulation with the criteria of normally-distributed data if $\alpha>0.05$ and abnormally-distributed data if $\alpha<0.05$. Results of the normality tests are shown in Table 1.

Table 1. Data normality test

\begin{tabular}{cccl}
\hline Tests & Groups & Sig & Description \\
\hline \multirow{2}{*}{ Pre test } & Game Modification & $\alpha=0.81,>0.05$ & Normally-distributed \\
& Conventional & $\alpha=0.73,>0.05$ & Normally-distributed \\
\multirow{2}{*}{ Post test } & Game Modification & $\alpha=0.76,>0.05$ & Normally-distributed \\
& Conventional & $\alpha=0.74,>0.05$ & Normally-distributed \\
\hline
\end{tabular}

The first hypothesis in this research states that game modification approach in learning physical education can significantly influence the physical fitness of the students. Results of the t-test conducted showed that the hypothesis is accepted $(\mathrm{t}=1.31, \mathrm{p}<0.05)$. The second hypothesis states that conventional method in learning physical education cannot significantly influence the physical fitness of the junior high students in the city of 
Padang. Results showed that this hypothesis is accepted whereby the conventional method did not significantly $(t=1.52, p>0.05)$ influence students physical fitness. The third hypothesis states that learning physical education with game modification approach is better in improving the students' physical fitness than that of the conventional approach. Results of the t-test showed that game modification approach is significantly better $(\mathrm{t}=1.42, \mathrm{p}<0.05)$ than the conventional approach in improving the physical fitness of the students.

\section{Conclusions}

Based on the results, it can be concluded that game modification approach significantly influenced and is better than the conventional approach to achieve the objectives of increasing students' physical fitness through physical education classes. Therefore, it is necessary to use the game modification approach so that students not only develop creativity in movement but is also able to improve their psychomotor skills and physical fitness. This research supports earlier research game modification approach in learning physical education.

\section{References}

Adisapoetra, I. Z. (1999). Panduan Teknis Tes \& Latihan Kesegaran Jasmani Untuk Anak Usia Sekolah. Jakarta: Menegpora.

Arman. (2007). Tingkat Kebugaran Jasmani Siswa SMPN 26 Lubuk Buaya Kota Padang Semester Januari -Juli 2007. Penelitian. Padang: Diknas.

Bahagia, Y., \& Suherman, A. (2000). Prinsip-prinsip Pengembangan dan Modifikasi Cabang olahraga. Jakarta: Depdibud. Dirjen Pendidikan Dasar Menengah, Bagian Proyek Penataran Guru SLTP Setara D-III.

Corbin, C. B. (1986). Texbook of Motor Development. New Yor: MCGraw-Hill Book Company.

Corbin, C. B., \& Lindsey, R. (2007). Fitness for Life. Newzeland: Human Kinetic.

Djaali. (2000). Pengukuran Dalam Bidang Pendidikan. Jakarta: PPs UNJ.

Djamarah, S. B. (1995). Guru dan anak didik dalam Inteaktif Edukatif. Jakarta:Rieka Cipta.

FINJ. (2009). KTSP Tahun 2006 Mata Pelajaran Pendidikan Jasmani Olahraga dan Kesehatan. Jakarta: FINJ.

Fox, E., Bowers, R., \& Foss, M. (1993). The Physiological Basis for Exercise and Sport. United States of America: Wm.C. Brown Communications. Inc.

Gabard, C., LeBlanc, E., \& Lowy, S. (1987). Physical Education for Children, Building the Foundation. New Jersey, USA: Practice-hall, Inc., Englewood Cliffs.

Mitchell, A., Griffin, L. L., \& Oslin, J. L. (1994). Tactical Awareness as a Developmentally Appropriate Focus for the Teaching of Games in Elementary and Secondary Physical Education. Journal the Physical Education.

Montolulu, B. E. F. (2005). Bermain dan Permainan Anak. Jakarta: UT.

Nieman, D. C. (1990). Fitness \& Your Health. California: Bull Publishing Company.

Pangrazi, D., \& Victor, D. (1989). Dynamic Physical Education for Elementary School Children. USA: Macmillan Publishing Company.

Said, H. (1979). Menuju Hidup Sehat dan Segar. Jakarta: Pusat Kebugaran Jasmani dan Rekreasi.

Sajoto, M. (1995). Peningkatan \& Pembinaan Kekuatan Kondisi Fisik dalam Olahraga. Semarang: Dahara Prize.

Samsuddin. (2008). Pembelajaran Pendidikan Jasmani Olahraga dan Kesehatan. Jakarta: Prenada Media Grup.

Sudjana. (1994). Disain dan Analisis Eksperimen. Bandung: Tarsito.

Suharjono. (2001). Pengaruh Kesegaran Jasmani Terhadap Prestasi Belajar Murid Sekolah Dasar. Yogyakarta: UNY.

Suharto. (2005). Petunjuk Teknis Pengukuran Kebugaran Jasmani. Jakarta: Departemen Kesehatan Republik Indonesia Direktorat Jenderal Bina Kesehatan Masyarakat.

Sukintaka. (1992). Teori Bermain Untuk D2 PGSD Penjaskes. Jakarta: Direktorat Jenderal Pendidikan Tinggi Proyek Pembinaan Tenaga Kependidikan.

Syarifuddin. (1999). Konsep Kesegaran Jasmani. Jakarta: PPPITOR Menegpora.

Tedjasaputera, M. S. (2005). Bermain, Mainan, dan Permainan Untuk pendidikan Usia Dini. Jakarta: Grasindo. 


\section{Copyrights}

Copyright for this article is retained by the author(s), with first publication rights granted to the journal.

This is an open-access article distributed under the terms and conditions of the Creative Commons Attribution license (http://creativecommons.org/licenses/by/3.0/). 